\title{
Construction Technology Used for the Reclamation of Seri Tanjung Pinang (Phase 2)
}

\author{
Nik Mohd Kamel Nik Hassan ${ }^{1, *}$, Nik Abdullah Mu'az Nik Mohd Kamel ${ }^{1}$, Muhammad \\ Fauzan Pauzi ${ }^{1}$ and Hee Min Teh ${ }^{2}$ \\ ${ }^{1}$ Dr. Nik \& Associates Sdn. Bhd., No 22 \& 24, Jalan Wangsa Delima 6, Seksyen 5, Pusat Bandar \\ Wangsa Maju, 53300 Kuala Lumpur, Malaysia \\ ${ }^{2}$ Department of Civil and Environmental Engineering, Universiti Teknologi PETRONAS, 32610 Seri \\ Iskandar, Perak, Malaysia
}

\begin{abstract}
The second phase of Seri Tanjung Pinang (STP2) aims to be an exemplar water front development that encapsulates the best of island living in Penang, Malaysia. STP2 offers a range of residential, commercial and leisure facilities to both local and international investors. Based on the geographical area, STP2 is divided into three packages, which are Package 2A (foreshore of Gurney Drive and the western region of the sand island), Package 2B (the southeast region of the sand island) and Package 2C (the northeast region of the sand island). It is an extension of the fully developed STP1 (Phase I) consisting of 240 acres of land reclamation works. Reclamation of the 253-acre STP2 Package 2A commenced in 2016 and is still underway, and reclamation of the remaining packages with the reclamation size of 507-acres shall kick off at a later stage. The main intention of this paper is to address the construction technology adopted since the commencement of the STP2 Package 2A reclamation. Prior to introduction to the various construction technologies used, the background of this reclamation project is first described. The overall construction sequence for the reclamation is also provided. The construction technologies applied for this project including turbidity control measures, delivery modes for construction materials, perimeter bund construction, placement of filled materials, soil improvement, sheet pile installation and construction of revetment, are respectively detailed in this paper.
\end{abstract}

\section{Project background}

Seri Tanjung Pinang (STP) is a seafront master-planned development on the northeast coast of Penang island, Malaysia, as shown in Fig. 1. The STP reclamation project by Tanjung Pinang Development Sdn Bhd (TPD), which is a subsidiary of public-listed Eastern \& Oriental Berhad (E\&O), comprises two phases which are STP1 and STP2. The 240 acres STP1 reclamation was fully completed in 2006 while the 760 acres STP2 project, which is located east of STP1, had commenced in 2016. It is expected to be fully completed in 2022

\footnotetext{
* Corresponding author: muazkamel@drnik.com.my
} 
[1]. The STP1 development includes detached, semi-detached and terraced houses, resort condominiums, executive apartments, low- and medium-cost apartments, retail promenades, a 40-berth marina, a public park and green spaces. Fig. 2 presents a bird's-eye view of the north and south sides of the STP1 development. The superiority of design concept and high liveability factor of STP1 had won this water-front development project an award in the Property Development Excellence category of 2016's in The Edge's Property Excellence Awards [2]. The world-class STP1 seafront master-planned development has emerged as one of Penang's attractive spots for locals and tourists, and is acknowledged as a catalyst for the growth and vibrancy of its vicinity, Tanjung Tokong [3].

The success of the STP1 development has driven TPD to embark on the ongoing STP2 reclamation. The STP2 project involves reclamation of a 760 -acre sand island located at the east of STP1, and 131 acres of land mass adjoining Gurney Drive and the south of STP1. Based on the construction sequence, the STP2 reclamation project has been divided into three packages, namely Package 1 (Phase 2A), Package 2 (Phase 2B) and (Phase 2C), as depicted in Fig. 3. Phase 2A comprises the 131 acres of land adjoining Gurney Drive and the 253-acre southwest region of the sand island. Meanwhile Phases $2 \mathrm{~B}$ and $2 \mathrm{C}$ cover the northeast region of the sand island, with the total reclamation area being 507 acres. The total land size of STP2, including the Gurney Drive adjoining land mass, is 891 acres. The total estimated filled volume is 30.6 million $\mathrm{m}^{3}$ of sand. A concept master plan has been formulated to develop the reclaimed land into becoming a public park and also the construction of Gurney Wharf for the new reclaimed land in front of the existing Gurney Drive (Persiaran Gurney). On the other hand, the developments at the STP2 man-made island include residential and commercial areas, public spaces, infrastructure and utilities. The proposed illustrative master development plan for Gurney Drive and the island are respectively shown in Fig. 4 and Fig. 5.

For the STP2 reclamation, the implementation of Phase 2A reclamation had commenced in 2016, followed by Phase 2B at the start of 2018. For the Phase 2A reclamation, formation of the southwest part of the sand island had been undertaken prior to the Gurney Drive reclamation works. Note that this paper will only address the construction technology used for the reclamation of STP2 Package 1 (Phase 2A).

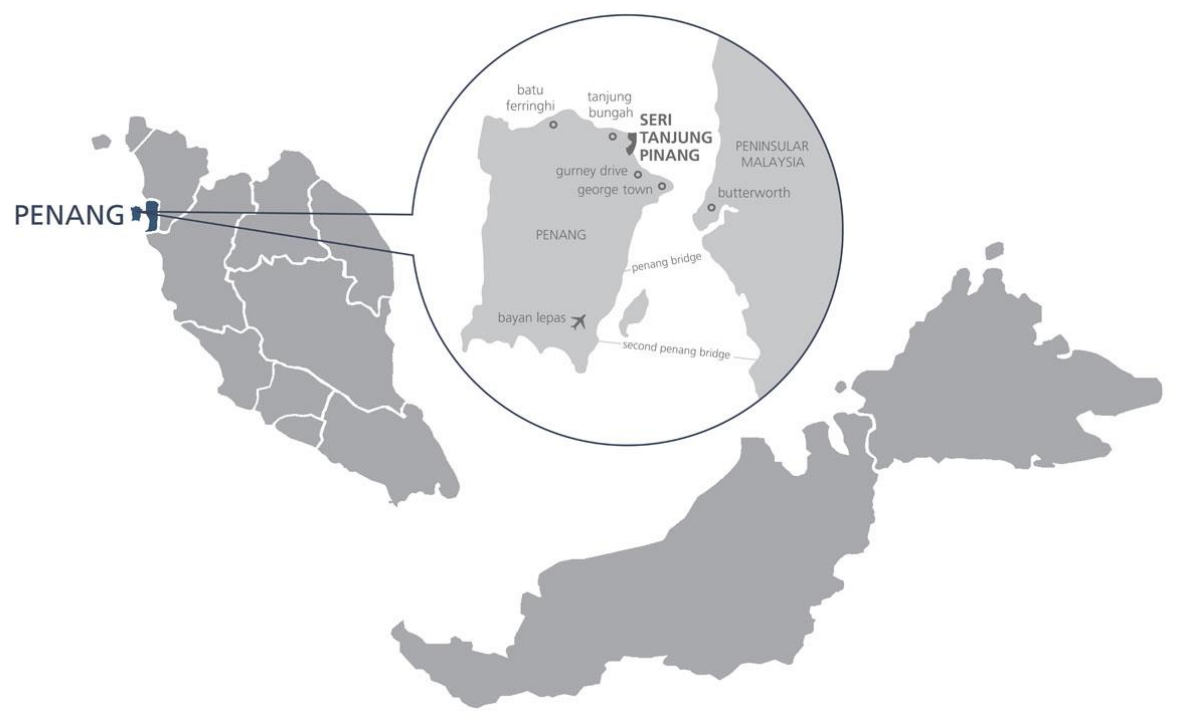

Fig. 1. Location of Seri Tanjung Pinang [1]. 


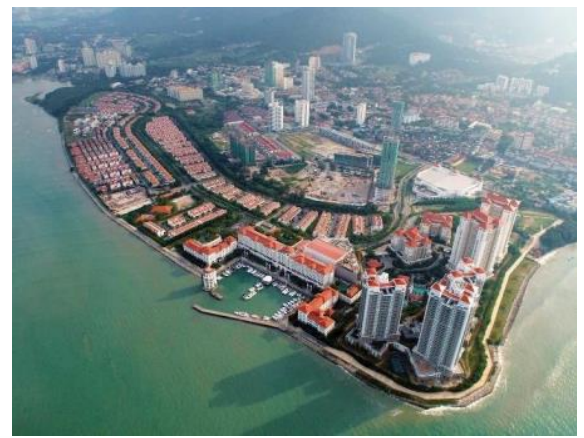

(a)

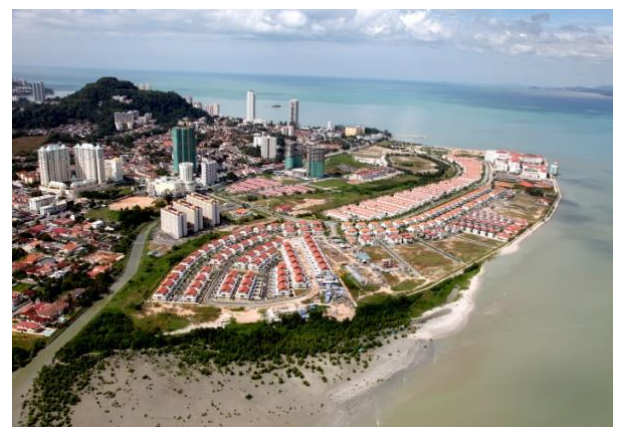

(b)

Fig. 2. Arial photographs of the STP1 development taken from (a) the north, and (b) the south.

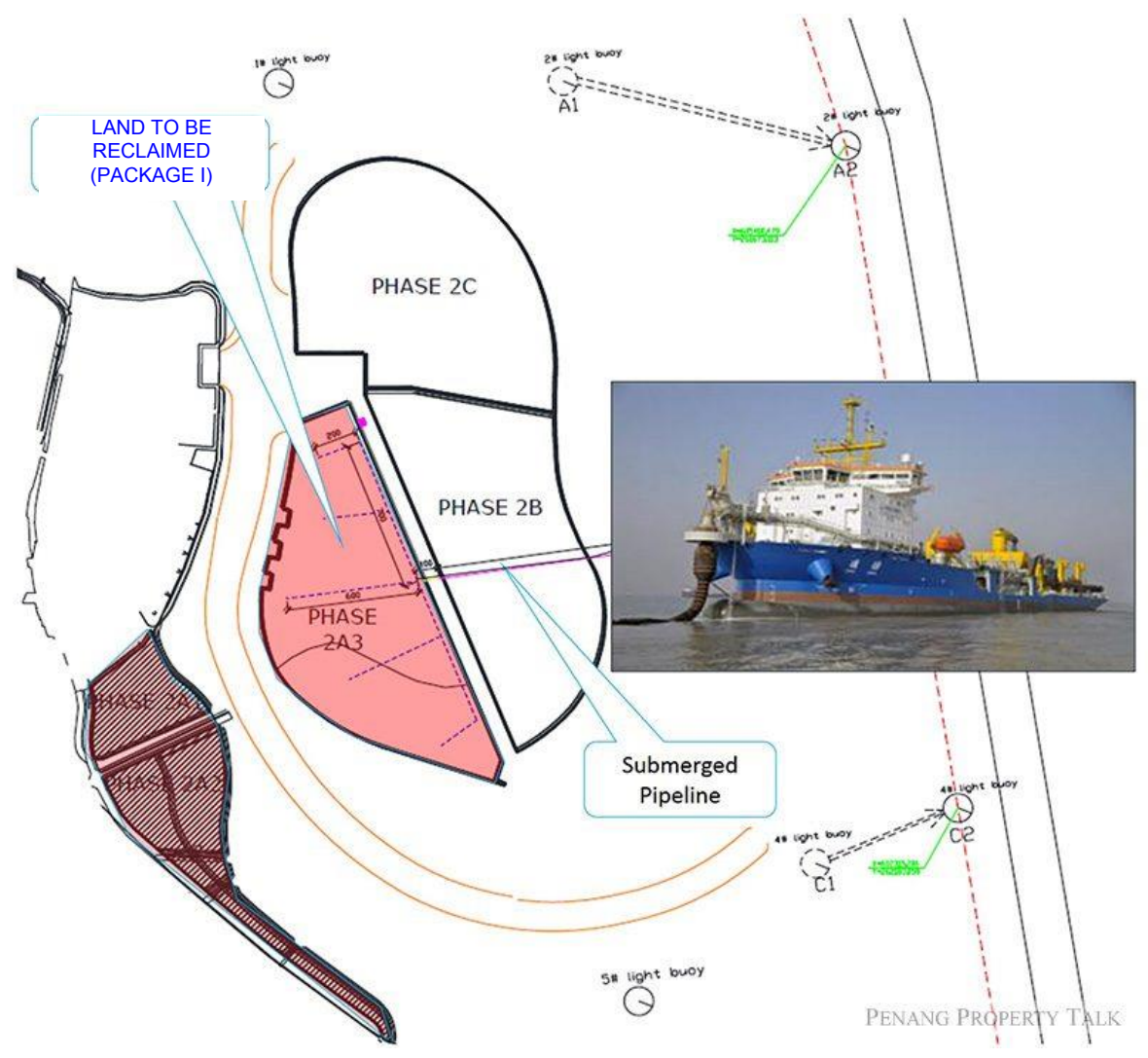

Fig. 3. STP2 reclamation packages - Phase 2A, Phase 2B and Phase 2C [4]. 


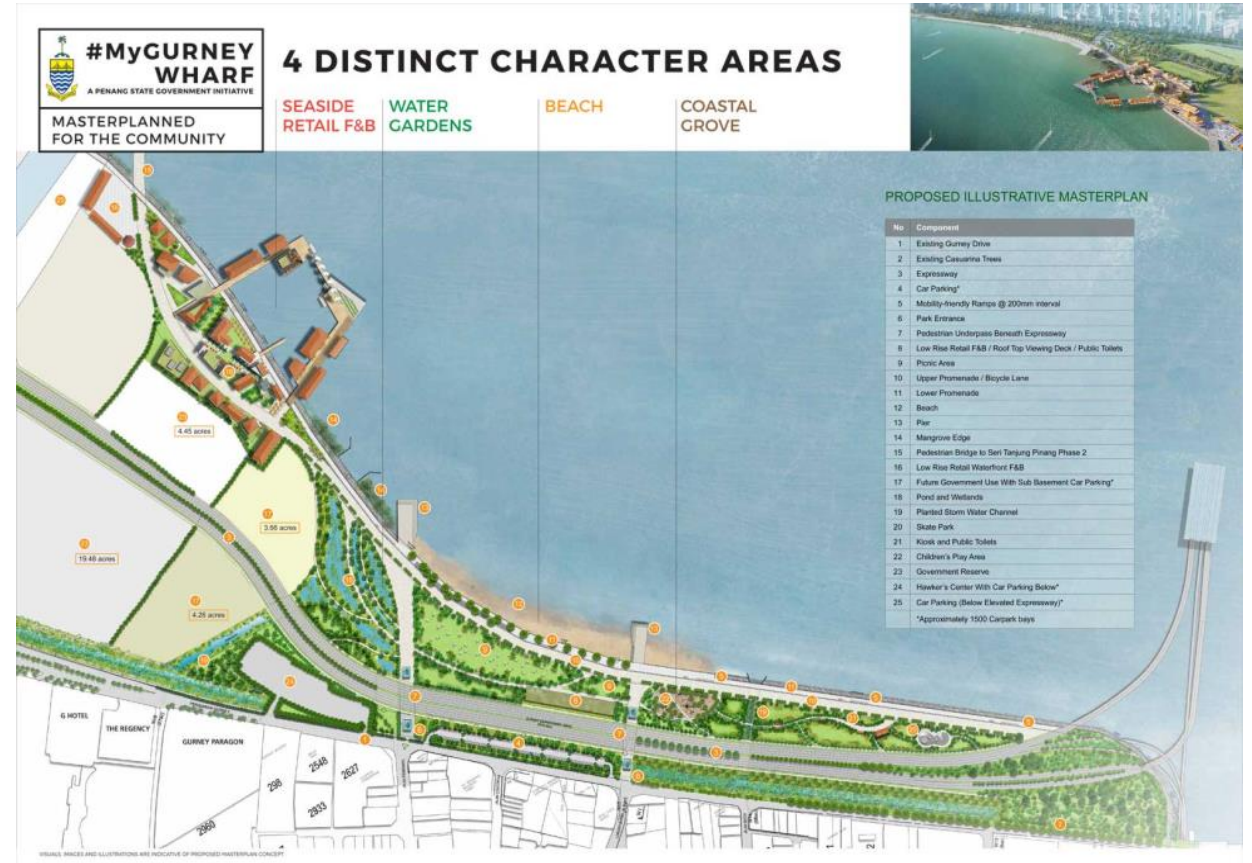

Fig. 4. Proposed illustrative master plan for Gurney Wharf [5].

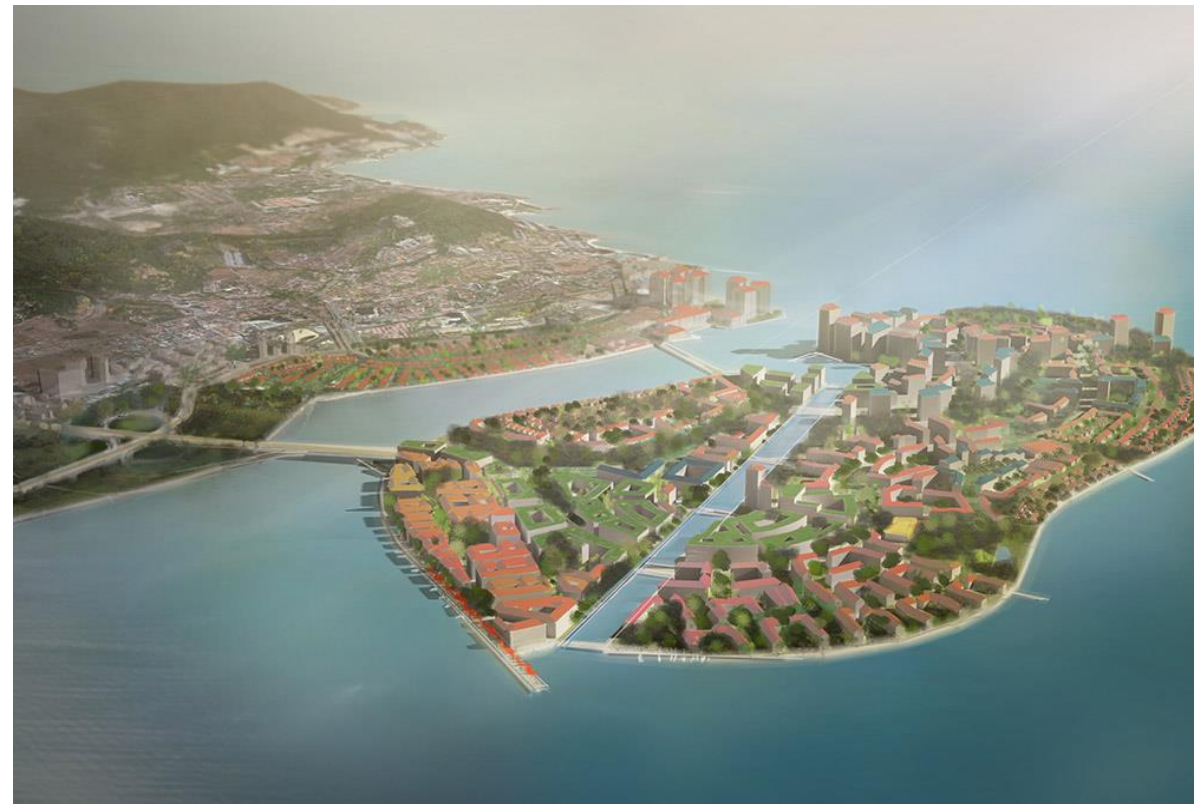

Fig. 5. Proposed illustrative master plan for the STP2 man-made island [5].

For STP2, TPD has appointed Dr. Nik and Associates Sdn. Bhd. as the Environmental Consultant, Engineering Consultant and the Engineer (Superintendent Officer), with China Communications Construction Company (M) Sdn. Bhd. as the Main Contractor to this project. Apart from land reclamation, the project also involves shoreline, topographic and hydrographic survey, channel and waterway dredging, soil improvement works, 
construction of coastal protection structures, sheet piles erection and compliance with the authorities' requirements.

\section{Construction sequence}

Prior to commencement of the STP2 reclamation works, pre-survey and setting-out were undertaken. The boundary of the project working area was demarcated with five lighted buoys as shown in Fig. 3. This is to ensure safe navigation and to keep out vessels that are not associated with this project. Subsequently, several arrays of turbidity control measures were also constructed and installed. These include the construction of the perimeter bund and also installation of silt curtain positioned close to the perimeter bund construction sites for prevention of sediment dispersion resulted from dredging and sand filling activities.

For Phase 2A - Gurney Drive, the seaward perimeter bunds were constructed using rocks, and the landward perimeter bunds were constructed using sand-filled tubes which are also known as geotubes. For Phase 2A - Island, the boundary of the island is formed by using two types of materials, which are sheet piles and rocks. Rocks, sand and sand bags were used initially as a perimeter bund to contain the sand fill material. Sand-filling works that started after the reclamation areas were predominantly enclosed by the perimeter bunds made from rocks, and sand bags. Once the sand fill was up to $+3.0 \mathrm{~m} \mathrm{CD}$ above the mean high water level, prefabricated vertical drain (PVD) were installed to the full depth of the compressible layer to drain off the pore water as part of the soil treatment. This is to expedite consolidation of the slow-draining soils. Subsequent sand filling took place at the $+3.0 \mathrm{~m} \mathrm{CD}$ platform that was installed with PVDs until the designated platform level $(+5.5$ to $+6.0 \mathrm{~m} \mathrm{CD}$ ). It should be noted that the platform at $+6.0 \mathrm{~m} \mathrm{CD}$ is $2.9 \mathrm{~m}$ above the highest astronomical tide (HAT) and more than $1.5 \mathrm{~m}$ above the recorded wave height at Tanjung Tokong during the 26 December 2004 tsunami event. Hence, the platform levels proposed for STP2 is regarded to be a safe design parameter with the inclusion of the safe environment against overtopping effects.

\section{Construction technology}

\subsection{Turbidity control measures}

In an effort to control the sediment dispersion resulted from reclamation and dredging activities, several turbidity control measures had been implemented on site. These include:

a) Construction of perimeter bunds

b) Installation of silt curtains

c) Online TSS monitoring system

\subsubsection{Construction of perimeter bunds}

There are three types of perimeter protection structures used to form the boundary of the STP2 reclamation sites, namely rock bunds, sand bunds and sandbags/geotubes, as previously depicted in Fig. 6. Meanwhile, Fig. 7 presents the completed perimeter protection structures of STP2 as being effective measures in mitigating sediment plume occurrence and the loss of filled materials. To create a platform for the construction of sand perimeter bunds, rainbow pumping by a sand conveyor barge was used to fill the sand material (Fig. 8)[6]. Note that sand feeding at the reclaimed area has to be handled with 
care so as to ensure the level of total suspended solid (TSS) complies with the environmental requirement as prescribed by the Department of Environment (DOE), i.e. 50 $\mathrm{mg} / \mathrm{L}$ and to minimise the loss of sand fill due to hydrodynamic effects. For STP2 reclamation, silt curtains were used to control the water turbidity level during sand filling operations. Once the platform level was higher than the high water level, the conveyor barge would transfer the sand directly on the completed bund section to minimize sediment dispersion. The stockpiled sand was carried by dump trucks to the designated locations for dumping.

The perimeter of the reclaimed site is marked by an array of trapezoidal rock bund, as schematically shown in Fig. 9, in which the average weight of each rock is between 200 and $115 \mathrm{~kg}$ depending on the section areas of the bund. [6]. The perimeter rock bund alignment was placed on the coastal protection alignment with the rock size material selected based on the size of the expected secondary armour rock for the subsequent permanent coastal protection works. Once the filling works are completed, the perimeter rock bund will be re-profiled in accordance to the profile of the final coastal protection works.

Besides preventing the sand from being washed back to the sea, the perimeter rock bund also provides protection to the reclaimed site from storm waves during the project's implementation period. These rocks were carried by barges to the reclaimed site for unloading to dump trucks using excavators. The dump trucks then transported the rocks to the designated area along the centre line of the perimeter bund once the platform was higher than the high water level. Fig. 10 shows the rock bunds built to demarcate boundaries of the STP2 reclamation [6].

For sandbags/geotubes, these were filled with sand taken from the stockpiled sand brought by the sand conveyor barge. The empty geotubes were prepositioned into the alignment at the lee side of Area 1 and Area 2 as shown in Fig. 6. Sand was then pumped into the geotubes using sand pump mixture and water. These geotubes are used as a barrier to keep out the fill materials from entering into the existing drainage system along Gurney Drive and as a preventive measure in controlling the mud heaving effect during filling works due to the presence of the soft original seabed materials at the reclamation site.

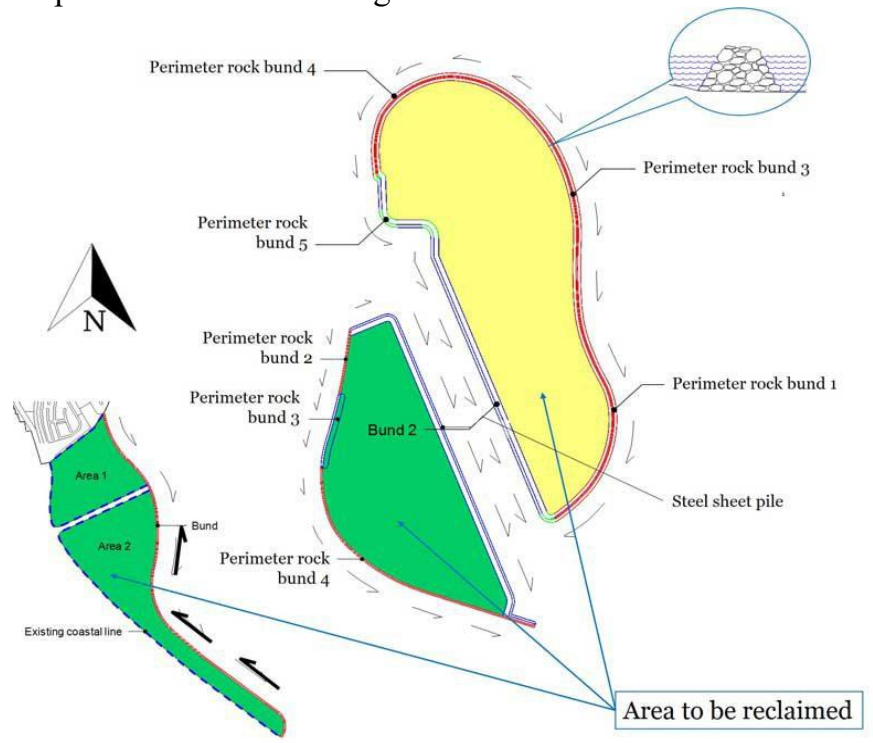

Fig. 6. Perimeter bunds of Phase 2A [6]. 


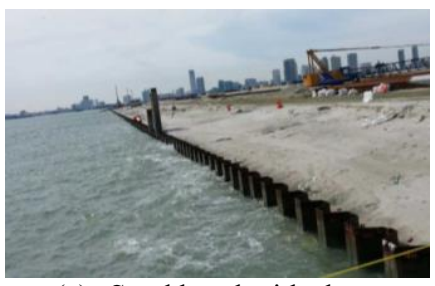

(a) Sand bund with sheet piles

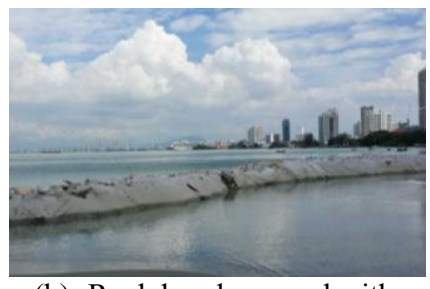

(b) Rock bund covered with geotextile

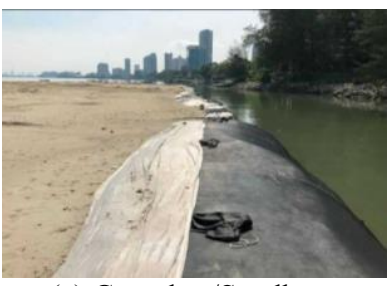

(c) Geotubes/Sandbags

Fig. 7. Perimeter protection used for the STP2 reclamation.

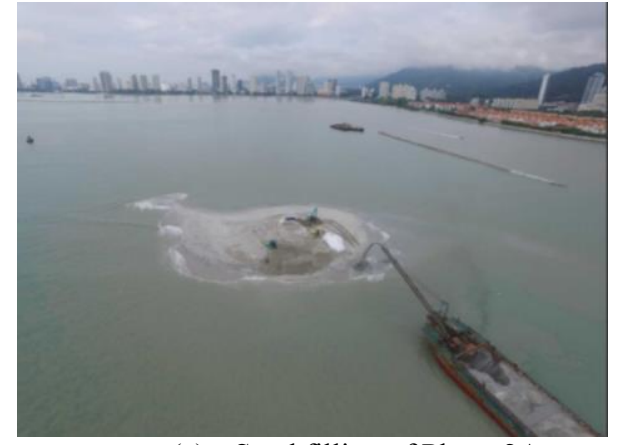

(a) Sand filling of Phase $2 \mathrm{~A}$

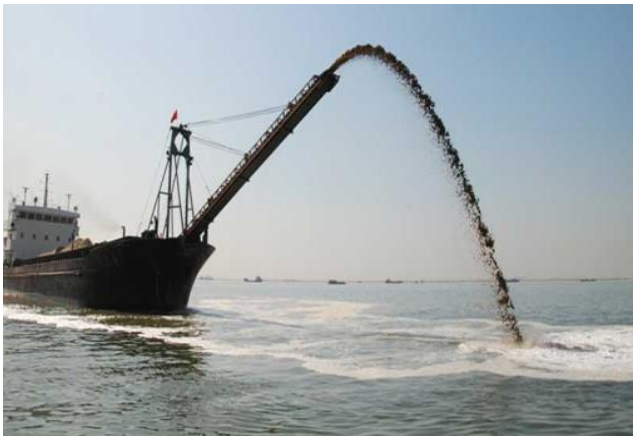

(b) Rainbow pumping

Fig. 8. Rainbow pumping using a sand conveyor barge [6].

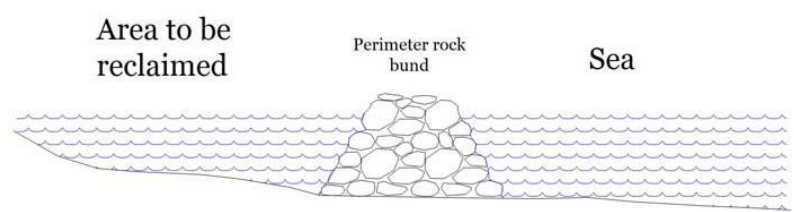

Fig. 9. Perimeter rock bund for the STP2 reclamation land [6].

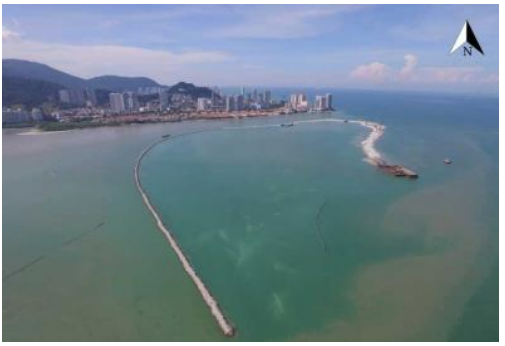

(a) STP2 artificial island

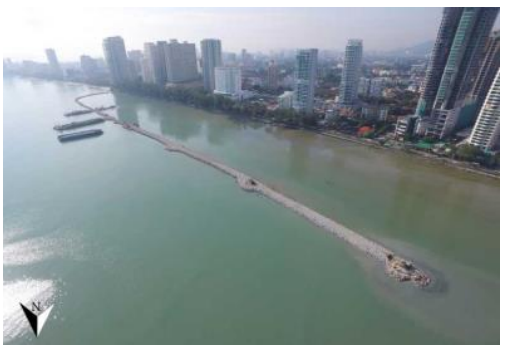

(b) The land off Gurney Drive

Fig. 10. Construction of perimeter bunds for the STP2 reclamation in 2016 [6].

\subsubsection{Installation of silt curtains}

To control sediment dispersion resulted from reclamation activities, a number of portable silt curtains were installed in front of the discharge outlets of the reclamation sites, as shown in Fig. 11(a). The silt curtain is made of woven polypropylene material and has high 
tensile strength against the environmental forces caused by waves and currents. The silt curtains were first prepared on land and came in $20 \mathrm{~m}$ sections. They were stitched and joined together at the eyelets, and the joints were further strengthened by steel plate connectors on each section. Fig. 11(b) depicts the typical cross section of the silt curtain used for the STP2 project. The silt curtain is extended with a minimum $2 \mathrm{~m}$ downward from a floater that is equipped with safety blinkers, and the curtain is held upright by means of chain weight as shown in the Fig. 11(b). This floating system is anchored to the sea bottom by mooring slings and sinkers. The silt curtain deployment procedures are demonstrated in Fig. 12. Concrete anchors are first placed to the seabed according to the layout design. Then, the silt curtain is towed to the proposed location for installation. One end of the curtain is tied to the concrete anchors using chain slings. The other end of the silt curtain is pulled by a work boat to the desired location for mooring purpose. The sections between both ends of the curtain are connected to their respective anchors located at both sides of the silt curtain. It is important to ensure that the silt curtain is floating upright at all time. The silt curtains were strengthened by a weight chain at the bottom of the curtain to ensure sufficient weight ballast of the curtain against the currents.

As reclamation progresses, both discharge outlet and silt curtain may need to be relocated accordingly to suit the project requirement. Due to its relatively low initial cost and ability to reuse, silt curtain installation has become a preferred control measure to reduce sediment dispersion to its vicinity. Nonetheless, the silt curtains require regular inspection and maintenance after installation. Some of common damages on silt curtain components reported for this project are detachment of weight chain from the curtain, snapped chains, entangled silt curtains, tear in curtain fabric, drifting of silt curtain from original position and damage to the floaters.

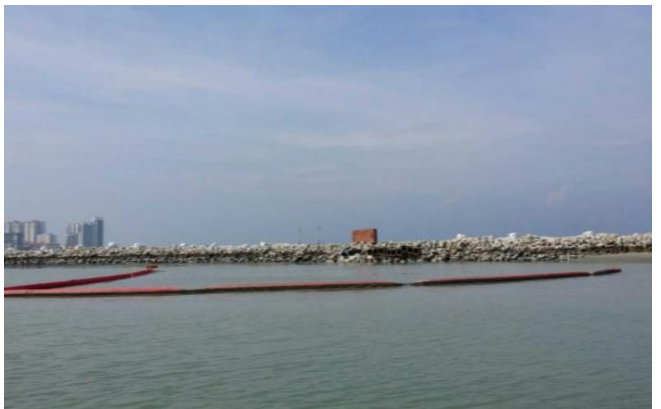

(a) Installation of silt curtains in front of a discharge outlet

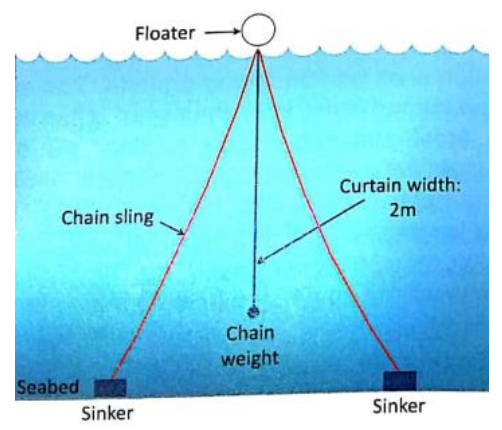

(b) Typical cross section of a silt curtain

Fig. 11. Silt curtain installation [7]. 


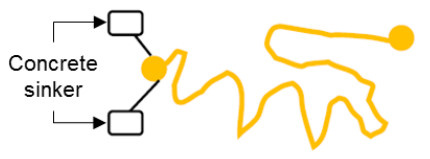

(1) End of silt curtain should be firmly secured with concrete sinker

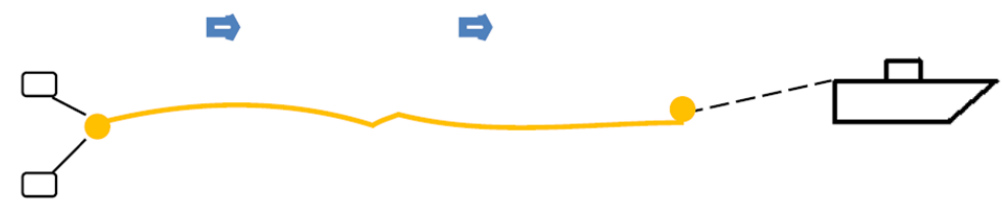

(2) Work boat will pull the other end of silt curtain to the exact position

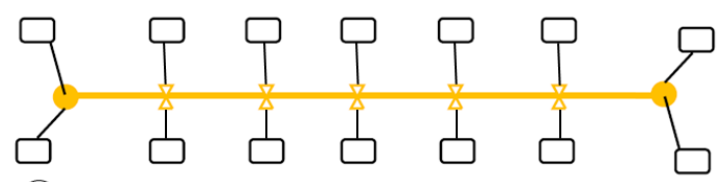

(3) Silt curtain will be connected with the concrete anchors placed earlier

Fig. 12. Silt curtain deployment procedures [7].

\subsubsection{Online TSS monitoring system}

It is vital to ensure that all of reclamation activities shall minimise and limit turbidity contained within the site area. With the demarcation of the project site using marker buoys, the total suspended solid (TSS) of the working area within the boundary must be restricted below the regulated permissible limit of $50 \mathrm{mg} / \mathrm{l}$. In implementing a self-regulation approach for TSS monitoring, the TSS limit boundary set along the marker buoys is actually much more stringent than the actual designated points set by the Department of Environment (DOE) that are located further away from the boundary line. Two well calibrated water quality sensors that are capable of recording water temperature, turbidity and $\mathrm{pH} / \mathrm{ORP}$ are installed at the selected buoys. The TSS values resulted from reclamation and dredging works are monitored $24 / 7$ via an online telemetry system so as to ensure the levels is within the permissible limit. The locations of the water quality sensor installation were chosen based on the probable sediment dispersion direction that correlates with the dominant current direction at the project site. Each sensor is programmed with a trigger limit of $45 \mathrm{mg} / \mathrm{L}$, which is $5 \mathrm{mg} / \mathrm{L}$ below the regulated permissible limit set by DOE. A warning notification is activated and delivered to the designated personnel if the TSS level measured is above $45 \mathrm{mg} / \mathrm{L}$. The dredging and reclamation operations will be adjusted accordingly or temporary suspended to avoid generation of excessive sediment plume in the sea environment. Fig. 13 illustrates a water quality sensor mounted on a marker buoy, and an overview of the response procedures is presented in Fig. 14. 


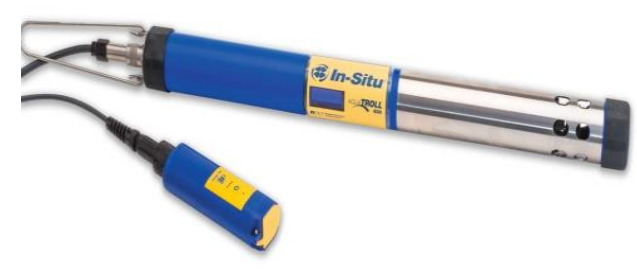

(a) Water quality sensor

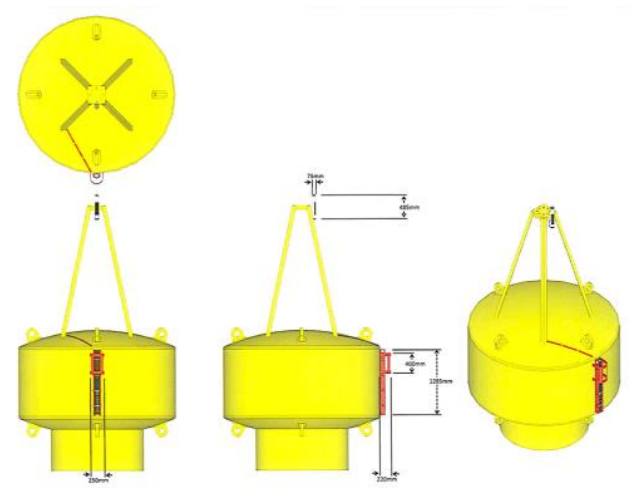

(b) Installation of water quality sensor on a marker buoy

Fig. 13. Water quality sensor attached to a marker buoy [7].

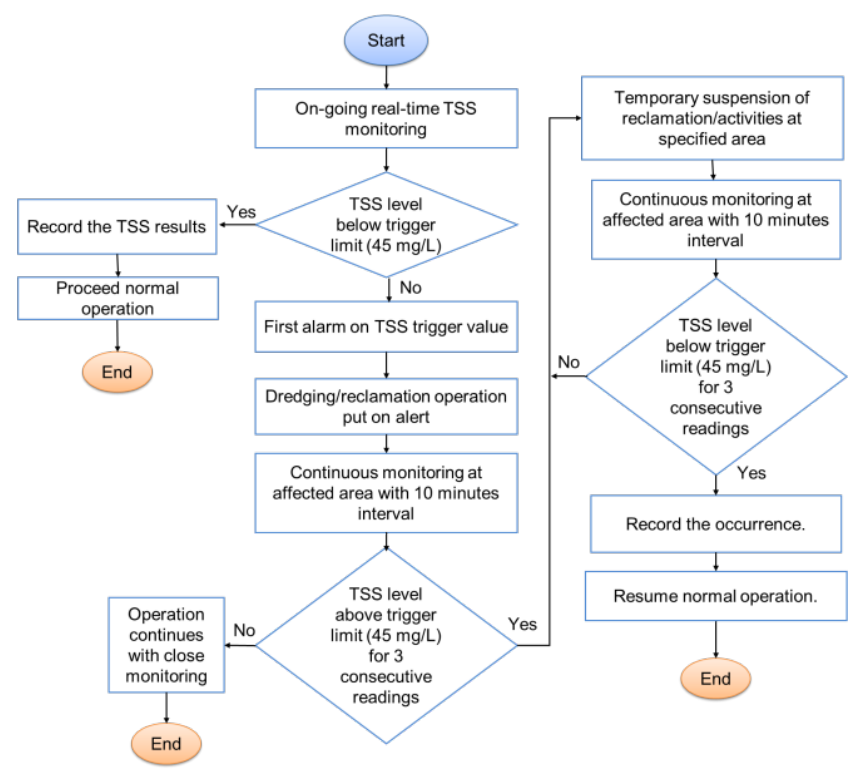

Fig. 14. TSS Online monitoring response procedures [7].

\subsection{Delivery of the construction materials}

The main materials used for STP2 reclamation are rock and sand. The latter used as the source of reclamation fill for the STP2 project due to its ease of handling, good drainage system and shorter consolidation period. To avoid water contamination during sand filling operation at the reclamation sites, licensed marine sand is chosen to be the filling material for this project. The marine sand is transported from approved sand mining areas to the project site via sea route using trailer hopper suction dredgers (TSHD), conveyor belt barges and flat-top barges. To ensure the imported marine sand meets the particle size distribution requirement as specified for this project, soil sampling has to be performed at the sand carrying barge prior to sand filling at the reclamation sites. The soil samples are then sent to an approved licensed laboratory for particle size distribution test - sieve 
analysis. Sand filling operation is permitted to start upon compliance with the stipulated requirements.

Meanwhile, rocks obtained from the approved quarries are transported overland by trucks to the respective offloading jetties, and carried to the project site using flat-top barges and tug boats. Prior to delivery of the rocks from the quarries, rock sampling is conducted to determine their physical properties (e.g. shape, size, mass, relative density, roundness, etc.) through a series of laboratory tests. Once the requirements of the quarry rock samples are met, the rocks of different sizes are transported to the sites in several batches using sea route. This comprises part of the Detailed Environmental Impact Assessment (DEIA) approval conditions whereby no land transport is permitted in order to alleviate the existing traffic problems encountered in Penang Island. The rocks are presorted and graded according to the required sizes at the quarry area. The arrival of vessels carrying the sand and rocks at the sites is demonstrated in Fig. 15. The sand carried by the sand barge or trailing suction hopper dredger (TSHD) is delivered to the reclamation site with the aid of an on-board pump, neighbouring pump barge and floating pipelines. More information on sand feeding is given in Section 3.4. Once berthed at the temporary jetty of the sand island, the quarry rocks of different sizes are then offloaded to dump trucks using an excavator and transported to the specified stockpile area for storage.

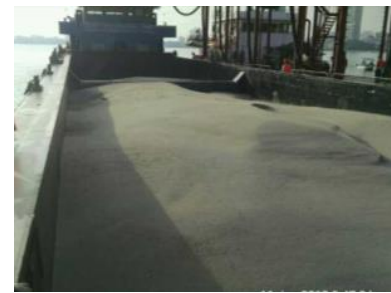

Marine sand

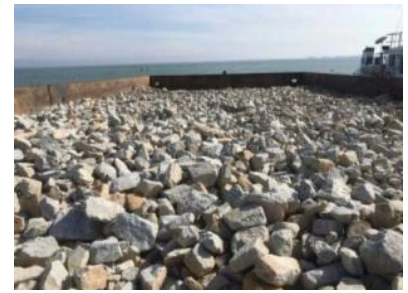

Bedding rocks

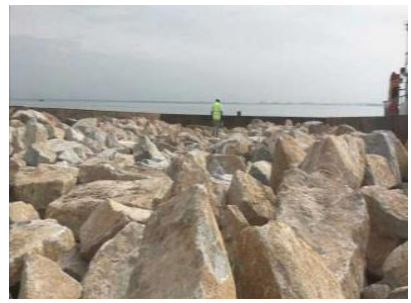

Secondary armour rocks

Fig. 15. Delivery of construction materials using barges.

\subsection{Placement of fill material}

\subsubsection{Phase 2A - Gurney Drive}

Upon completion of the rock bunds and the discharge outlets along the inner boundary of the reclamation area, placement of fill material (i.e. sand) may then commenced at the Phase 2A reclamation site. To prevent the loss of fill material from the reclamation area, the rock bunds are covered by a layer of geotextile. It should also be noted that several openings are made along the rock bund so as to prevent water stagnation within the enclosed area that potentially poses drainage problems along Gurney Drive.

Reclamation at Gurney Drive is done by a conveyor barge via a pump vessel located at a designated location within the pre-dredged access channel between Gurney Drive and the proposed STP2A sand island. Both the sand-carrying vessel and the pump vessel are not able to berth at the near-shore of Gurney Drive due to draft limitations. The sand conveyor barge berths therefore alongside the pump vessel, as shown in Fig. 16(a), before loading the sand into the pump vessel. The pump vessel transfers sand to the reclamation area via floating pipes ranging between 1000 to $1500 \mathrm{~m}$ as shown in Fig. 16(b).

Meanwhile Fig. 16(c) shows sand pumping through a discharge pipe from a dredger north of the Gurney Drive reclamation area. The choice of reclamation method used has to 
be cautiously opted for this project. Improper reclamation method used at the site which is filled with weak seabed soil may lead to the formation of mud wave in front of the fill.

For Phase 2A - Gurney Drive, sand spreading using smaller tubes as shown in Fig. $16(d)$ is implemented. The sand discharge outlets are assisted with manpower to ensure the sand material is evenly spread on the soft original seabed material. Subsequently, levelling of the sand fill is performed using bulldozers. Upon filling of sand up to $+3.0 \mathrm{~m} \mathrm{CD}$ at the reclaimed area, pre-fabricated vertical drain (PVD) installation work takes place to treat and consolidate the ground. Later, the reclamation resumes until the platform reaches the final desired designed level at $+5.0 \mathrm{~m} \mathrm{CD}$. Once the design platform is reached, the pump barge is located to a new location within the access channel as the reclamation progresses.

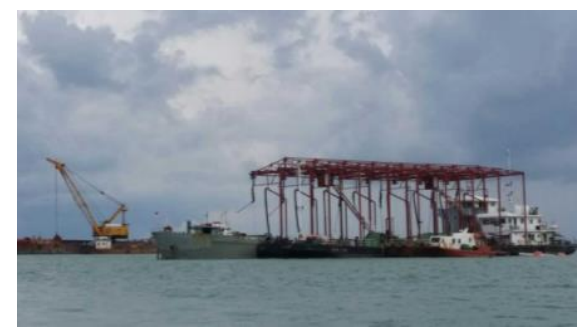

(a) Sand conveyer barge and pump vessel

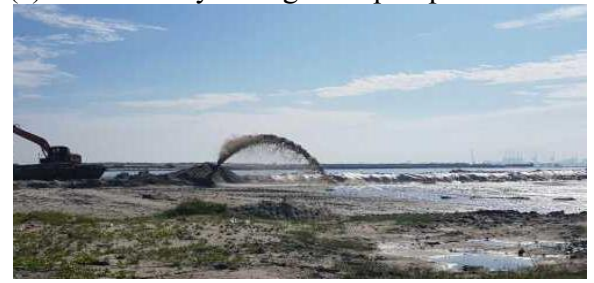

(c) Pumping sand through a discharge pipe from a dredger

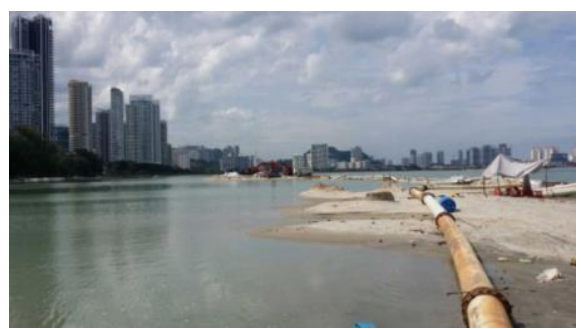

(b) Delivery of sand via pipeline

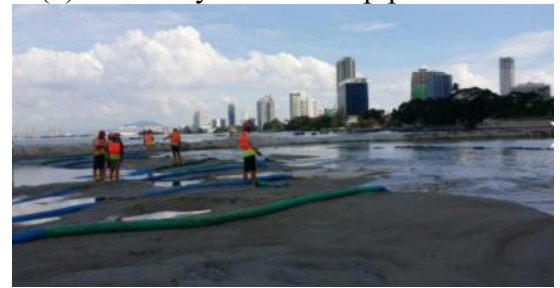

(d) Spreading of sand on weak soil seabed

Fig. 16. Sand filling at Gurney Drive reclamation area.

\subsubsection{Phase $2 A-$ Island}

Filling works at the artificial island commenced when the perimeter bund had been completed. A discharge outlet was built at the southeast end of the island to allow water drainage from the island during the filling process. Two reclamation methods were adopted to sand-feed the island, namely (1) hydraulic filling using a self-propelled trailing suction hopper dredger (TSHD) via pipelines (Fig. 17a), and (2) direct filling using sand conveyor barges. The TSHD transports the sand from the approved sand source to the project site. Due to draft limitation, the TSHD has to be anchored near Penang Port's Northern Channel with approval from the Malaysian Marine Department and Penang Port's authority. A Marine Traffic Risk Analysis (MTRA) was performed to assess the risks associated with the mooring location of the TSHD and the requirements for the safe manoeuvring and navigation process. The TSHD is connected by an approximately $2 \mathrm{~km}$ submerged pipelines for the filling work at the sand island as shown in Fig. 17(b). The delivery pipeline used for this sand filling is a combination of floating pipe, submerged pipe and amphibious pipe of different lengths. The full load of the TSHD is about $20,000 \mathrm{~m}^{3}$ per trip.

The reclamation procedures are similar to those adopted for Phase 2A - Gurney Drive as described in Section 3.3.1. In the beginning, the filled material is spread and stockpiled starting from the central of the island (see Fig. 18), and then the sand was re-distributed by 
bulldozers and transported by dumping trucks to extend the land towards the sea, as shown in Fig. 19. To ensure the density degree of the fill materials, the dry reclamation method is particularly suitable for foreshore locations with underlying competent seabed soil [9]. A number of bulldozers are used to level the ground for attainment of the desired level. Similarly, reclamation is conducted until $+3 \mathrm{~m} \mathrm{CD}$, followed by PVD installation and another sand feeding until the platform level reaches $+5 \mathrm{~m} \mathrm{CD}$. It is worthwhile to note that the PVD installation is undertaken at $+3 \mathrm{~m} \mathrm{CD}$ that is well beyond the Mean High Water Spring (MHWS) at this area, i.e. $+2.71 \mathrm{~m} \mathrm{CD}$; hence, the risk of seawater intrusion and flooding are under control.

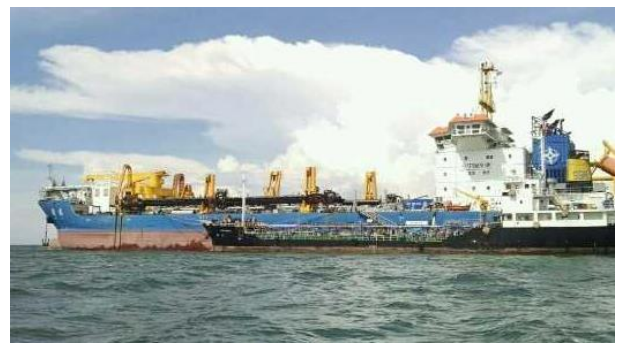

(a) Self-propelled trailing suction hopper dredger (TSHD)

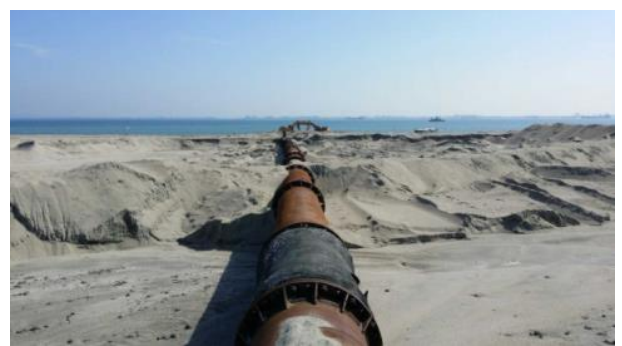

(b) Pumping sand through a discharge pipe from the TSHD

Fig. 17. Transportation of sand from a trailing suction hopper dredger (TSHD)

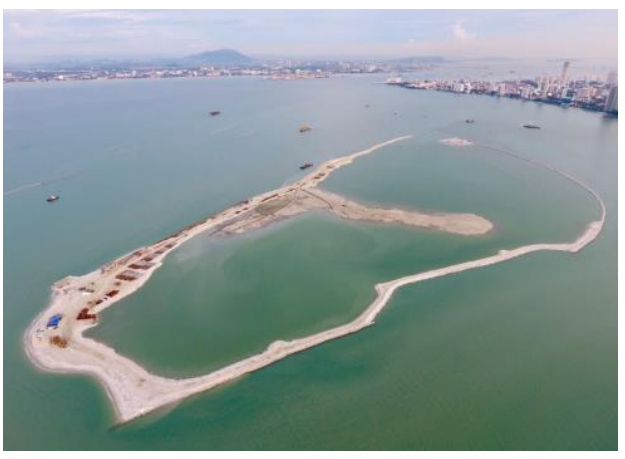

Fig. 18. Sand feeding at the artificial island enclosed by perimeter bunds by a TSHD [4].

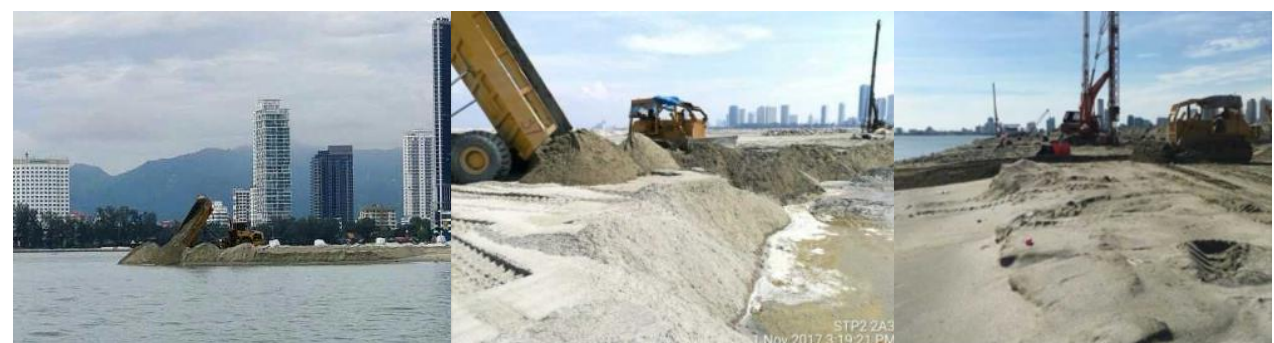

(a) Sand transported from the stockpile site to the water edge (b) Sand dumping at the water edge by dump trucks (c) Platform levelling using bulldozers

Fig. 19. Dry reclamation method. 


\subsection{Soil improvement}

Reclamation on soft ground will require a substantial amount of time to achieve primary consolidation due to low permeability and long drainage path of the underlying soft clay [9]. Non-uniformity of the underlying soil and the uneven spread of future loads on soil may lead to differential settlement and resulting in damage to the structures built on the newly reclaimed land. Hence, soil improvement is required to increase the effectiveness stress throughout the profile of the compressible soil layer. This can only be done by dissipation of pore water pressure through draining out of pore water.

The STP2 reclamation project adopted pre-fabricated vertical drain (PVD) installed at certain intervals in the compressible soil mass to improve drainage capacity of the soil. PVD is a composite geo-synthetic system consisting of an inner core and an outer filter jacket as depicted in Fig. 20 [10]. It has a width of $100 \mathrm{~mm}$ and a thickness of $6 \mathrm{~mm}$. PVD technology is preferred due to its low material cost and efficient installation technique. The flexible core forms flow grooves on both sides along its length, and the jacket serves as a filter to maintain the hydraulic capacity of the grooves allowing passage of fluids into the drain core while preventing clogging by soil intrusion. As a result, PVD consolidates the compressible soil mass much faster due to shorter drainage path. Fig. 21 compares the drainage path of the soil medium with and without PVDs. PVDs are installed by a hollow steel mandrel encasing the wick drain material. The mandrel is driven into the ground by a stitcher attached to an excavator carrier, as shown in Fig. 22 [12]. The mandrel is driven by a vibrating force. At the base of the mandrel, the wick is looped through a steel anchor to secure the drain in place. Once the desired depth is reached, the drain is anchored and the mandrel is extracted. The mandrel is withdrawn 15 to $20 \mathrm{~cm}$ above the surface for the wick drain to be cut.

For the STP2 reclamation, PVDs are installed once the fill level has reached $+3.0 \mathrm{~m}$ CD. Fig. 23 presents the PVD installation at the sand island. Before surcharging, several monitoring equipment are installed for future monitoring of the ground condition. These equipment include benchmarks, surface settlement plate, subsurface settlement plate, piezometers etc. Upon completion of installation of the monitoring equipment, a continuous filling to the required level and subsequent addition of the surcharge material of $3 \mathrm{~m}$ thickness are performed. The overburden of the surcharge weight is used to act as a preload to accelerate the consolidation of the underlying clay layer that is naturally saturated with water. Under compression by the surcharge, pore water is drained out onto the surface through the PVDs. The surcharge material is transported using TSHD or belt conveyor vessels and then loaded onto dump truck for placement before being trimmed by bulldozers.

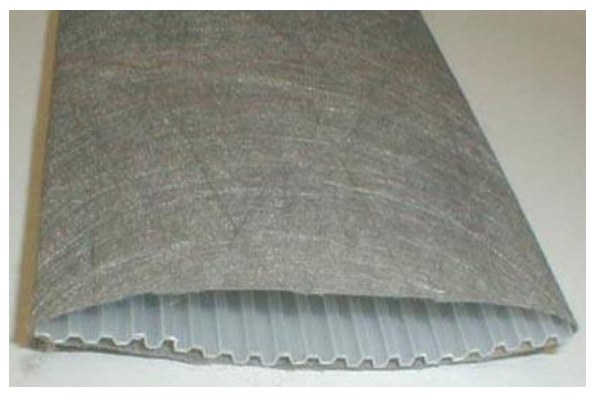

Fig. 20. Prefabricated vertical drain made of an inner core and an outer filter jacket [10]. 


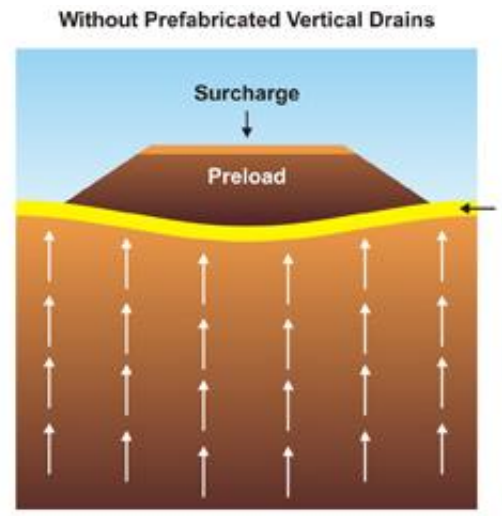

Long Drainage Paths

(a)

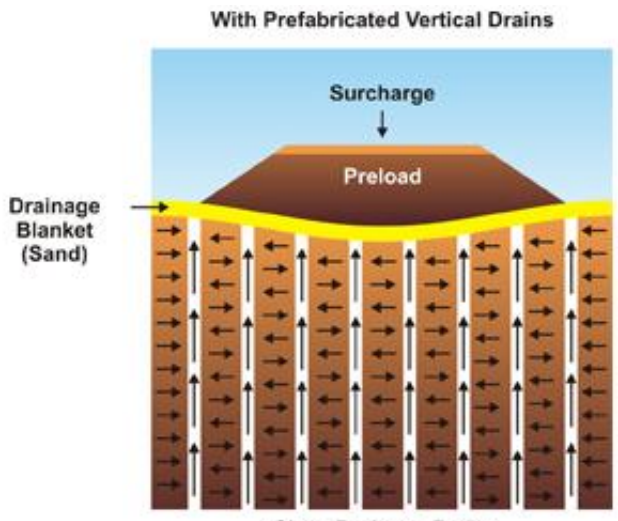

Short Drainage Paths

(b)

Fig. 21. Drainage paths: (a) without PVDs, and (b) with PVDs [11].

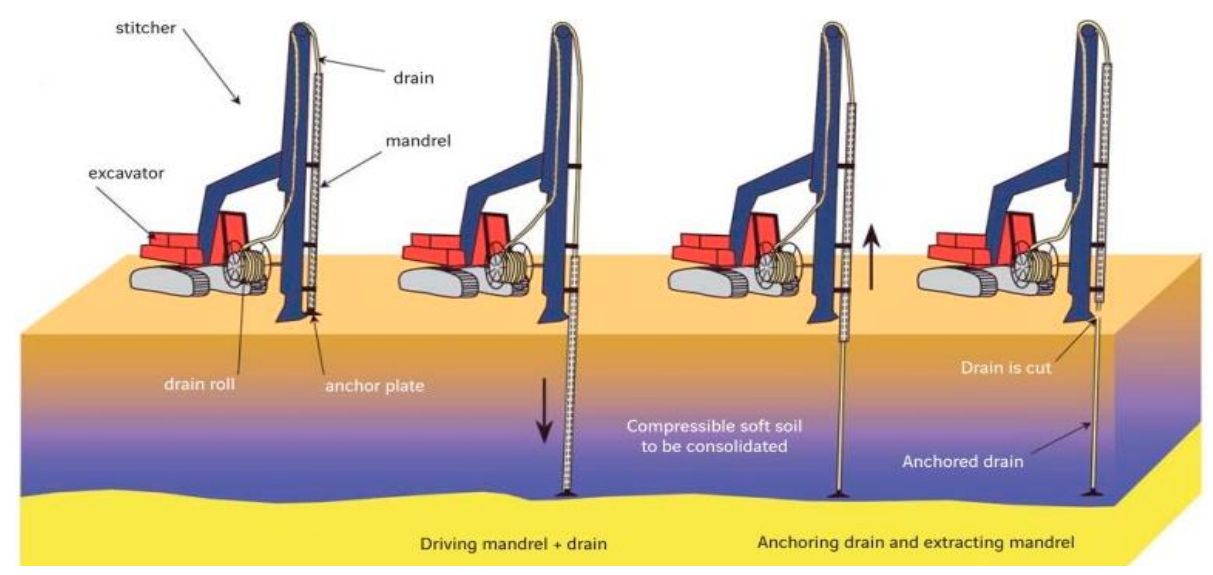

Fig. 22. PVD installation procedures [12].

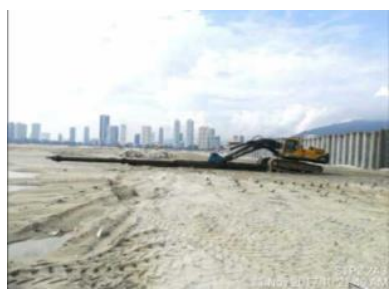

(a) The hollow steel mandrel laid on the ground

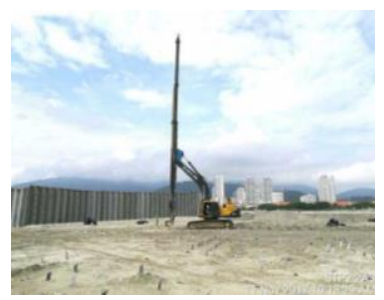

(b) The hollow steel mandrel is lifted by an excavator

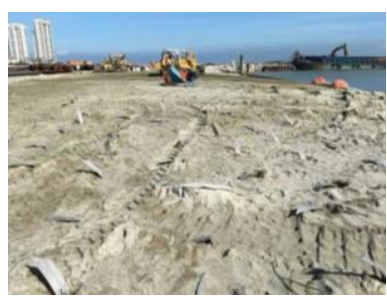

(c) The access wick drain is cut

Fig. 23. PVD installation at the STP2 sand island.

\subsection{Sheet pile installation}

A sheet pile wall is commonly used for reclamation works as a retaining wall providing vertical face edge between the reclaimed land and waters. Sheet piles are suitable to be 
used for deep and soft seabed conditions. For the soft seabed condition at the STP2 project area, sheet pile installation requires sufficient penetration depth for stability. At certain areas, additional anchoring system is adopted to further strengthening stability of the marine soil. For the Phase 2A sand island, single length sheet piles of $24 \mathrm{~m}$ are used to provide perimeter protection along the east of the island and the private marinas, as depicted in Fig. 3. Each pair of sheet pile is made of two units of interlocked Z-shape sheet pile as presented in Fig. 24 [12]. For the perimeter section consisting of the weak soils, sheet piles of $30 \mathrm{~m}$ are used and the active side of the piles are pulled by horizontal anchors (tie-rods) that are connected to a 3-m anchor sheet piles placed at $120 \mathrm{~m}$ landward of the sheet pile wall. The conceptual drawing of the sheet pile with tie-rod installation for soil stability is shown in Fig. 25 [13]. All sheet piles used for this project were coated with several layers of protective paint to counter corrosion in the marine environment.

Prior to sheet pile installation, an array of steel plates was inserted into the external edges of the reclaimed land, i.e. several meters seaward from the sheet pile installation location, to serve as a temporary seawall (see Fig. 26). The void at the leeside of the temporary seawall was subsequently filled with sand by using an excavator. Once the working platform was completed, sheet pile installation work commenced to start. The sheet piles were first vibrated into the ground to a certain penetration depth using a vibratory hammering machine, followed by impact hammering of the piles penetrating the hard soil layers to the desired depth. The complete sheet pile wall was formed by connecting the joint of neighbouring sheet pile section in sequential installation as shown in Fig. 27.

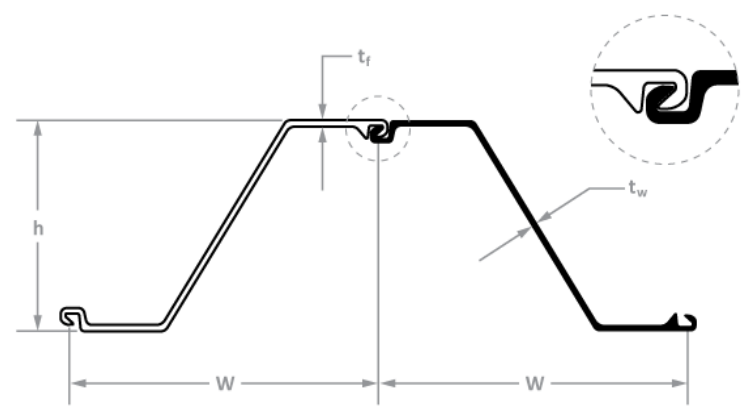

Fig. 24. Plan view of a pair of the Z-shape sheet pile [12].

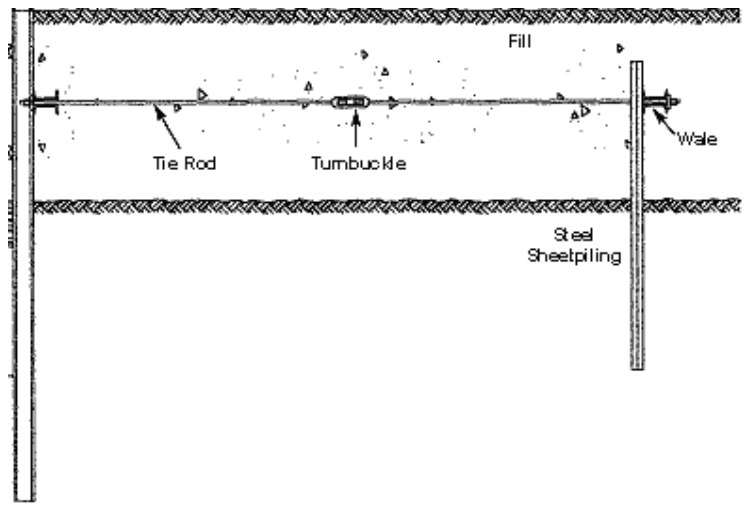

Fig. 25. A sheet pile pulled by a tie rod [13]. 


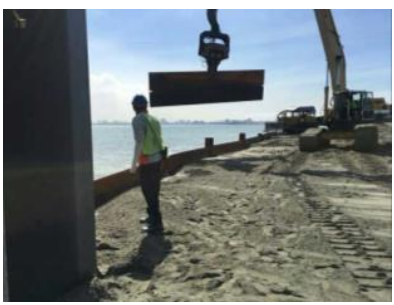

(a) Steel plates were inserted to the external edges of the reclaimed land to serve as a temporary seawall.

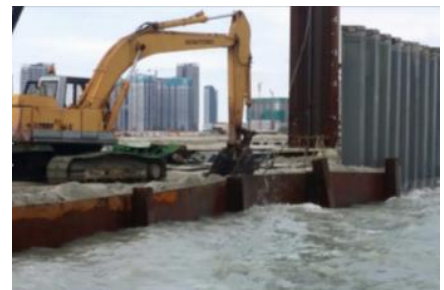

(b) Sand filling to fill the void at the leeside of the temporary seawall using excavator.

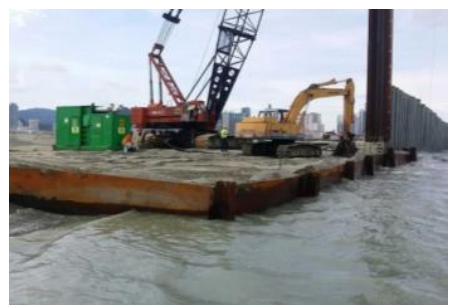

(c) Completed platform for sheet pile installation.

Fig. 26. Construction of temporary external platform for sheet pile installation.

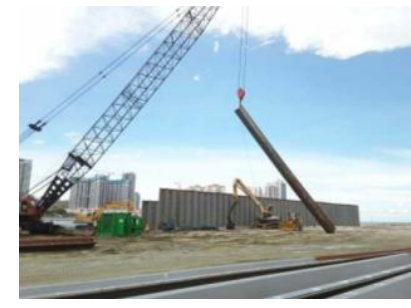

(a) Sheet pile lifting using a crane

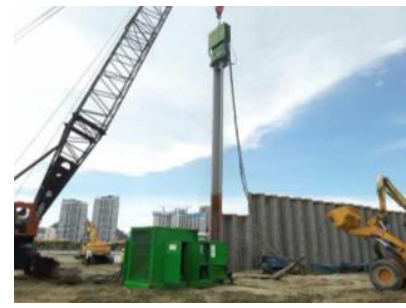

(b) Penetration of sheet piles using a vibratory hammering machine

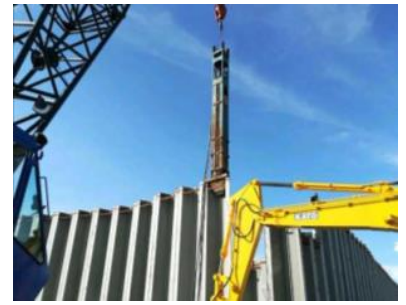

(c) Penetration of sheet piles to the finished level using an impact hammer

Fig. 27. Sheet pile installation.

\subsection{Revetment (Coastal Protection)}

A rock revetment is a form of protection placed on a sloping surface or structure to stabilize and protect against erosion as a result of waves and currents. A rubble mound revetment was chosen as the main coastal protection structure for the STP2 island. This locally available material is deemed suitable to be placed at the soft seabed due to its high adaptability to uneven soft ground settlement. Moreover, the material is relatively economical to construct and maintain.

A complete rock revetment consists of an armour layer as an outer most top layer, a filter layer (or under-layer) and possible other sub-layers [14]. The armour layer of the revetment allows for some limited degree of movement or deformation when interacting with waves, while maintaining contact with the under-layer or filter layer. The filter layer is laid to provide drainage to the revetment, avoiding the build-up of excessive hydraulic pressures beneath the armours, and preventing loss of fine sediments. The filter layer may be a granular filter, a geotextile, or both built beneath the armour layer. An initial conceptual revetment design is given in Fig. 28. Note that due to confidentiality the revised version of the revetment design has not been presented in this paper.

Coastal protection using revetment is necessary to protect the completed profile of the reclaimed land from erosion induced by wave, current and tide. The construction of revetment structure of the STP2 project commenced after the formation of the reclaimed land. For the STP2 project, perimeter rock bunds were first constructed to mark the boundary of part of the reclamation areas (see Section 3.3). Upon completion of the reclamation, the existing rock bunds were further re-profiled to be a revetment structure providing adequate protection to the reclaimed land. The revetment design used for the 
STP2 project varies with sections depending on the seabed level and distribution of wave energy along the shorelines with the adoption of 100-years return period and the possible tsunami wave forces in mind. In general, the revetments of STP2 are made of a primary armour rocks, secondary armour rocks, bedding rocks and filter rocks. The graded stones and armour stones used for this construction are granites rocks, in which the specific gravity is between 2.4-2.6 and the density is about $26 \mathrm{kN} / \mathrm{m}$. The toe of the revetment seated on the centreline of the scour rocks is to provide toe stabilization and protection from possible scour of the foreshore in front of the structure and to hold the rock armour. Apart from the rock armour layers, geotextile filters were also used in the permanent revetment design to segregate between underlying layers and as a filter layers. The construction sequence of revetments (up to secondary armour layer) is sequentially presented in Fig. 29.

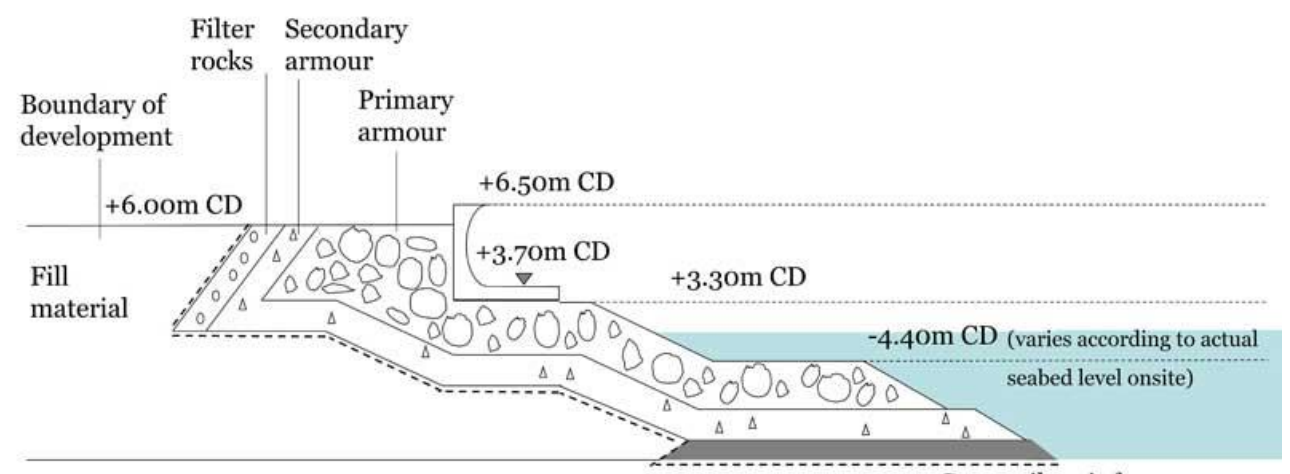

Geotextile reinforcement

Fig. 28. Typical cross section of a revetment [6].

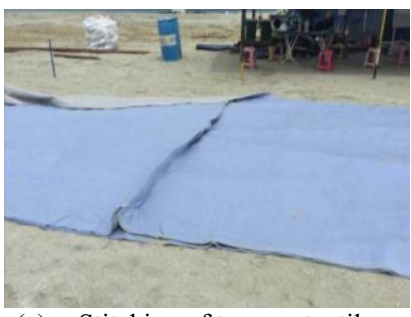

(a) Stitching of two geotextile layers at site

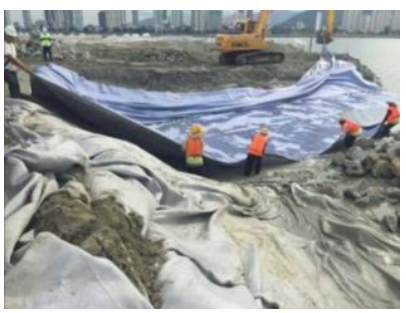

(d) Adjustment of the geotextile layer laid on the excavated section

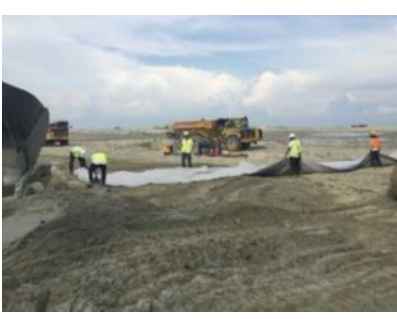

(b) Preparation of geotextile layer for laying at the excavated section

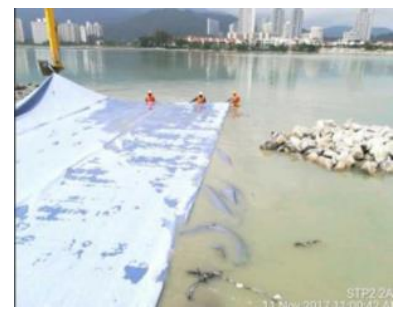

(e) Flattening of the geotextile layer using excavator and manpower during low tide

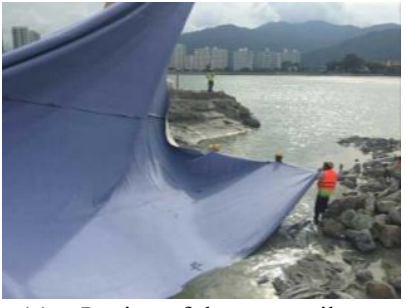

(c) Laying of the geotextile layer at the excavated section using both excavator and manpower during low tide

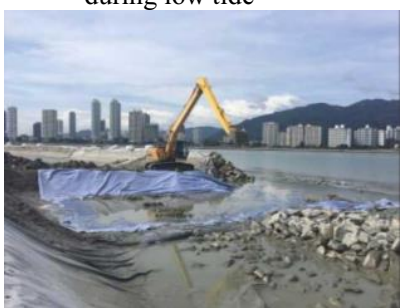

(f) Placement of bedding rocks on the geotextile layer using an excavator 


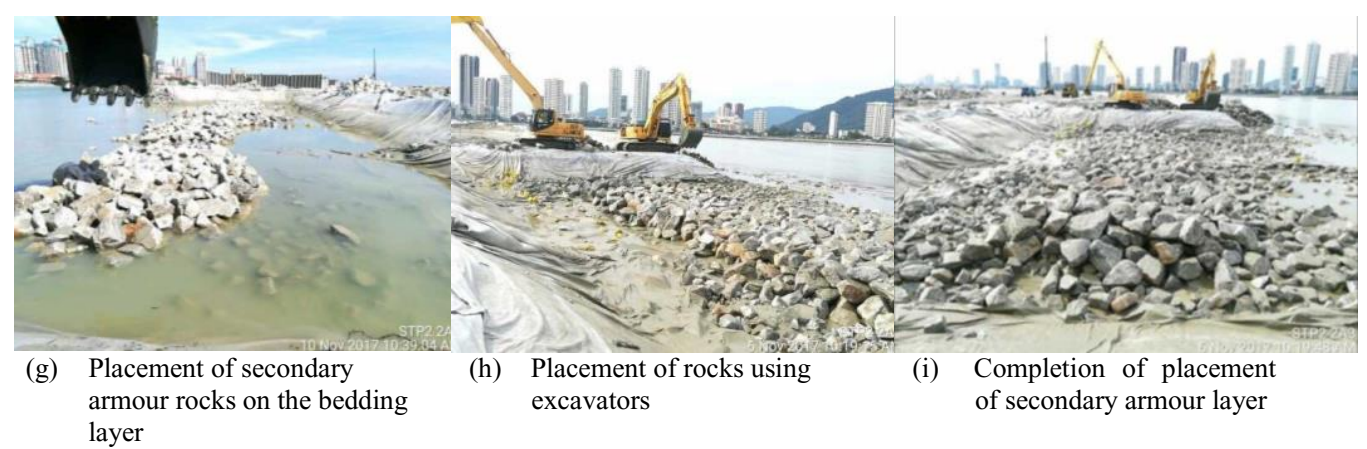

Fig. 29. Construction sequence of revetment

\section{Conclusion}

The second phase of Seri Tanjung Pinang (STP2) involves reclamation of a total of 30.6 million $\mathrm{m}^{3}$ of sand over 891 acres of land. There are various construction technologies adopted for this project. These include construction of perimeter bunds, silt curtain installation, online total suspension solid monitoring system, delivery modes for construction materials, placement of filled materials, soil improvement, sheet pile installation and construction of revetment. The choice of construction methods and technologies were largely dependent upon availability of the required resources, i.e. construction materials, equipment and expertise. In addition, compliance with the environmental and authority approval conditions is also a major factor in determining the most suitable method of construction for the STP2 reclamation work. The construction methods and technologies used for the STP2 reclamation have been explicitly deliberated with the help of figures and photographs taken during on-site operations. It is hoped that this paper has provided valuable insight to the readers on coastal reclamation to the readers.

The authors would like to thank Tanjung Pinang Development Sdn. Bhd., Dr Nik and Associates Sdn. Bhd. and China Communications Construction Company (M) Sdn. Bhd. for sharing the relevant information and data to be included as part of this paper. The authors also wish to express their gratitude to Dr Nik and Associates Sdn. Bhd. for funding this paper.

\section{References}

1. http://www.stp2.my/faq.php

2. http://www.stp2.my/stp1-today.php

3. E\&O Edition 23, December 2017, Eastern \& Oriental Berhad. (2017)

4. http://www.penangpropertytalk.com/2017/03/seri-tanjung-pinang-phase-2/

5. http://www.stp2.my/gurney-wharf-background.php

6. http://www.stp2.my/technology.php

7. The Proposed Reclamation of Seri Tanjung Pinang (Phase II) Development (STP2), Penang - Environmental Management Plan (Rev 02), Tanjung Pinang Development Sdn. Bhd., Oct 2017 (2017)

8. http://img2.penangpropertytalk.com/wp-content/uploads/2017/03/Perimeter-rockbund-for-the-land-to-be-reclaimed-off-Gurney-Drive-and-STP2.jpg 
9. M.W. Bo, V. Choa, Reclamation and Ground Improvement, Singapore: Thomson Asia Ptd Ltd (2004)

10. http://www.geoengineer.org/education/web-based-class-projects/select-topics-inground-improvement/prefabricated-vertical-drains? showall=1\&limitstart=

11. http://www.retech.in/prefa.html

12. http://www.skylinesteel.com/globalnav/products/steel-sheet-piling/z-piles

13. http://www.williamsform.com/Marine_Tie_Back_Tie_Rods/Tie_Back_Tie_Rods_App lications/tie_back_tie_rods_applications.html

14. K. McConnell, Revetment System Against Wave Attack - A Design Manual, London: Thomas Telford Publishing (1998) 